\title{
THE FORMATION OF SHEAR MORAINES: AN EXAMPLE FROM SOUTH VICTORIA LAND, ANTARCTICA
}

\author{
By R. A. Souchez
}

(Fonds National de la Recherche Scientifique et Service de Géomorphologie, Université Libre de Bruxelles, Bruxelles, Belgium)

Abstract. An analysis of the margin of the ice sheet in the upper Ferrar Glacier area of south Victoria Land, Antarctica, shows that the shear hypothesis and the theory of Weertman are both of value if an attempt is made to explain the formation of the morainic deposits of this area.

Three types of debris layer have been observed within the glacier:

i. Silty and sandy layers, with a slight dip towards the interior of the glacier, are separated from one another by white bubbly ice and blue dense ice at the edge of the glacier. They have resulted from a freezing-in process due to the formation of segregation ice and upwarping near the margin of the ice sheet.

ii. Fault planes in the glacier, filled with slabs and gravel, are the result of shearing which has occurred along and transformed thermal-contraction fissures. The debris has been scraped from the glacier bed, carried into the ice and ultimately transported along these planes.

iii. Three coarse debris layers of different ages associated with major shear zones at the boundary between stagnant and active ice.

Due to favourable circumstances, the debris layers of Weertman have been observed to be faulted by shear planes of the second type.

RÉsumé. La formation de moraines de cissaillement: un exemple du sud de la Victoria Land, Antarctique. L'analyse de la bordure de l'indlandsis, dans la région du Ferrar Glacier, Victoria Land, Antarctique, montre qu'à la fois la notion de cisaillement et la théorie de Weertman expliquent la formation des dépôts morainiques de cette région.

Trois types de couches de débris ont été observées dans la glace:

i. des couches de sable et de limon à faible pendage vers l'intérieur du glacier sont séparées l'une de l'autre par de la glace bulleuse blanche et de la glace bleue dense. Elles résultent du processus de regel lié à la formation de glace de ségrégation et du relèvement des lignes de courant à la périphérie de l'indlandsis.

ii. des plans de faille remplis de plaquettes et graviers sont le résultat d'un cisaillement utilisant et transformant les fissures de contraction thermique. Les débris sont arrachés du lit et transportés le long de ces plans de cisaillement.

iii. trois couches de débris grossiers d'âges différents associées aux zones de cisaillement majeures à la limite entre glace stagnante et glace active.

Grâce à des circonstances favorables, les couches de débris de Weertman ont été observées faillées par les plans de cisaillement du deuxième type.

Zusammenfassung. Die Bildung von Schermoränen: Ein Beispiel aus Sud-Victoria Land, Antarktika. Bei der Untersuchung des Randes des Eisschildes im Gebiet des oberen Ferrar Glacier in Süd-Victoria Land, Antarktika, erweisen sich sowohl die Schertheorie als auch die Weertman'sche Theorie als wertvoll für den Versuch einer Erklärung der Bildung der Moränenablagerungen des Gebietes.

Im Gletscher wurden 3 Typen von Schuttlagen beobachtet:

i. Tonige und sandige Schichten, die mit leichter Neigung gegen das Innere des Gletschers einfallen, sind am Gletscherrand durch weisses, blasenreiches Eis und durch blaues, dichtes Eis voneinander getrennt. Sie sind das Ergebnis eines Einfrier-Prozesses infolge der Bildung von Absonderungseis und Aufbiegung nahe am Rande des Eisschildes.

ii. Verwerfungsflächen im Gletscher, gefüllt mit Blöcken und Schotter, wurden durch Scherung erzeugt, die entlang von Sprüngen-entstanden unter Wärmekontraktion-eintrat und diese dabei veränderte. Der Schutt wurde vom Gletscherbett aufgenommen, ins Eis getragen und schliesslich entlang dieser Ebenen transportiert.

iii. Drei Lagen groben Schuttes verschiedenen Alters, gebunden an grössere Scherzonen an der Grenze zwischen stagniertem und bewegtem Eis.

Infolge günstiger Umstände konnte eine Faltung der Weertman'schen Schuttlagen durch Scherflächen des zweiten Typs beobachtet werden.

\section{INTRODUCTION}

Because of my participation in the U.S. Antarctic Research Program as a foreign scientist, I was able to spend two summers at McMurdo station (in 1965-66 and r $966-67$ ) in order to carry out a field programme on glacial erosion and deposition in south Victoria Land. During these periods, the upper part of the area between Mackay and Skelton Glaciers was systemati- 
cally investigated to determine the erosional and depositional activity at the boundary of the ice sheet with its outlet glaciers. The aim of this paper is to present the results of observations and analyses made on an interesting morainic field in the upper part of Ferrar Glacier. Due to favourable circumstances, this deposit throws some light on the general problem of the formation of shear moraines (Bishop, I957; Schytt, 196r ; Swinzow, 1962). Other papers concerning glacial erosion and deposition in this area will be presented elsewhere.

The term "shear moraine" has been criticized by Weertman (I96I), who prefers the name "Thule-Baffin moraine" to the commonly used designation. However, I shall continue to use it not only because of its ease of usage but also because of the fact that, in the case studied, Weertman's hypothesis, which is valid for certain parts of the morainic deposit, cannot explain it as a whole.

The shear moraine of upper Ferrar Glacier is neither wholly the result of the influence of a single shear plane appearing at the surface nor simply the result of the upwarping at the margin of the glacier (in the ablation zone) of debris layers incorporated within the ice by a freezing-in process. It is a complex depositional feature in relation to the dynamics of the margin of the ice sheet, comprising both upwarping and faulting of the ice along different planes or zones of weakness having different directions and ages.

\section{Description of the Area}

The upper Ferrar Glacier area, which is located in south Victoria Land approximately $130 \mathrm{~km}$. from McMurdo station and $60 \mathrm{~km}$. from the coast, consists of Beacon Sandstone plateaux dissected by large outlet glaciers coming from the ice sheet. The two outlet glaciers of the area are respectively Taylor Glacier at the north and Ferrar Glacier which is connected by small tributaries to the former (Fig. I). The Beacon sediments rest sub-horizontally (with a slight dip towards the west) on the basement Skelton Group, which does not appear in the area considered here. Dolerite sills intrude the Beacon rocks and dykes are also present. The contrast between the dark, highly jointed dolerite and the relatively massive lightcoloured sandstone is the striking feature of the area. The white-yellow cliffs of Beacon Sandstone consist of orthoquartzite (not strongly cemented, rounded quartz grains) in the Devonian part of the section. In the upper Permian part, carbonaceous siltstones are frequent, e.g. at Mount Feather which is $3 \mathrm{~km}$. from the morainic field studied (personal communication from D. Matz). The altitude of the area can be easily obtained from the recent topographic map (scale I : 250,ooo; published by the U.S. Geological Survey; Taylor Glacier sheet). The surface of the glacier is at an altitude of $1,800 \mathrm{~m}$. while Mount Feather, the highest point, reaches $2,985 \mathrm{~m}$.

Part of the ice descending from the ice sheet and flowing in the direction of Ferrar Glacier enters, to the south-west of Altar Mountain, a large cirque cut in the Beacon rocks which are capped by a dolerite sill. The bottom of the cirque, which can be subdivided into three smaller units, is now ice-free and covered with ground and recessional moraines. The margin of that part of upper Ferrar Glacier which enters it is fringed by the important shear moraine that is discussed here.

\section{Description of the Morainic Field}

The problem of the formation of this morainic deposit can be subdivided into three parts:

(a) The incorporation of debris within the ice at the bed of the glacier.

(b) The migration of debris from the glacier bed to the surface.

(c) The behaviour of debris at the glacier surface and its influence on differential ablation.

Due to favourable circumstances, these three questions can be approached in the present case, but before dealing with them it is desirable to give a general description of the morainic field. 


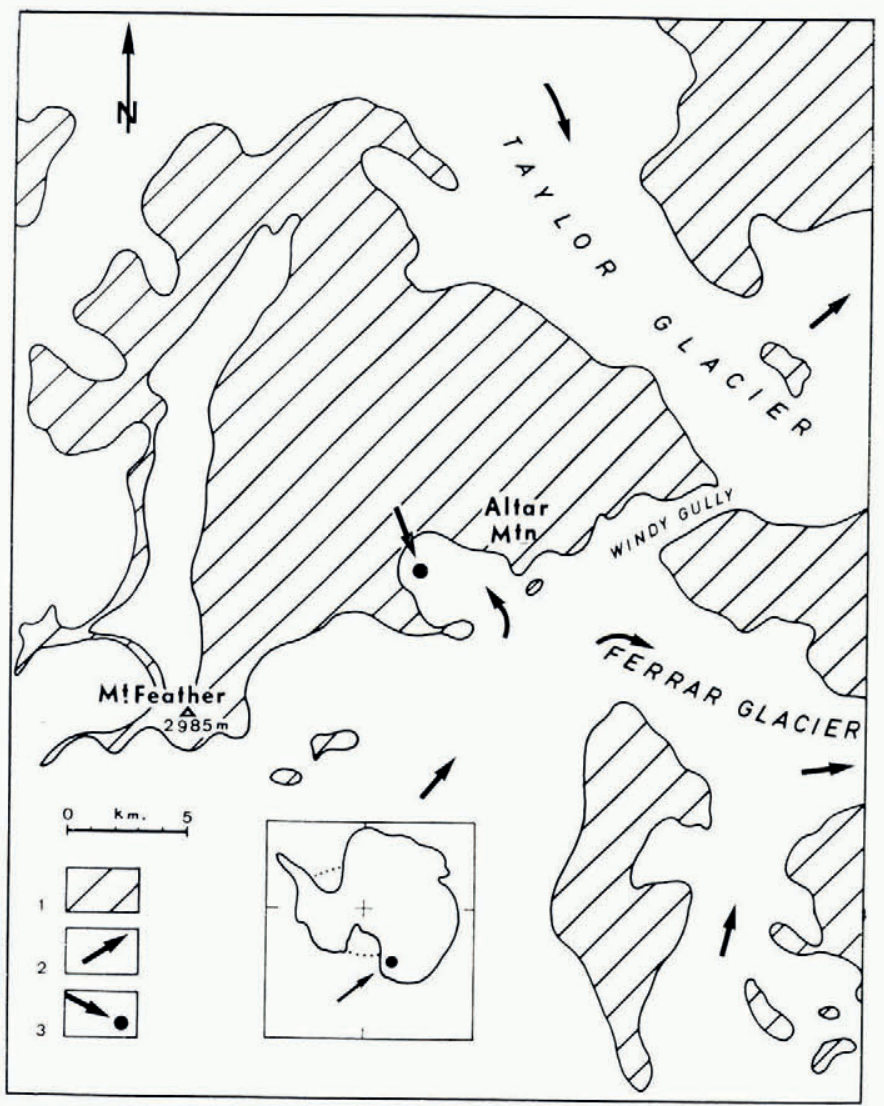

Fig. I. Location of the upper Ferrar Glacier area and of the morainic deposit studied 1. Ice-free arca. 2. Direction of glacier movement. 3. Location of the morainic deposit studied

Figure 2 gives a general idea of the morainic field considered here. It can be seen that it is possible to divide it into two units: the central body (regions A and B) and the two great ridges to the east (region $\mathrm{C}$ ).

The whole of the deposit is ice-cored and the blue glacier ice is always visible beneath several centimetres of debris. Traversing from the outer part of the central body of the morainic deposit (facing the cirque) to the inner part, the following five zones can be distinguished, especially in region A (Figs. 2 and 3 ):

(a) A marginal channel filled with regelation ice at the contact between the patternedground moraine $\left(a^{\prime}\right)$ and zone $b$.

(b) Scree deposits resulting from sliding of the moraine on glacier ice.

(c) Glacier ice appearing at the surface as a result of sliding of the debris veneer. The slope decreases progressively so that the starting force needed for this process is no longer reached at the upper limit of zone c. Because of the appearance of the glacier ice, layers of debris are visible within the ice. The observation made in the next paragraph is essential to the understanding of the origin of this deposit.

(d) A continuous veneer of debris resting on glacier ice. This zone could extend as far as the marginal channel (zone a) if zones b and c were to disappear. This is the case in region $\mathrm{B}$ of the morainic field. 


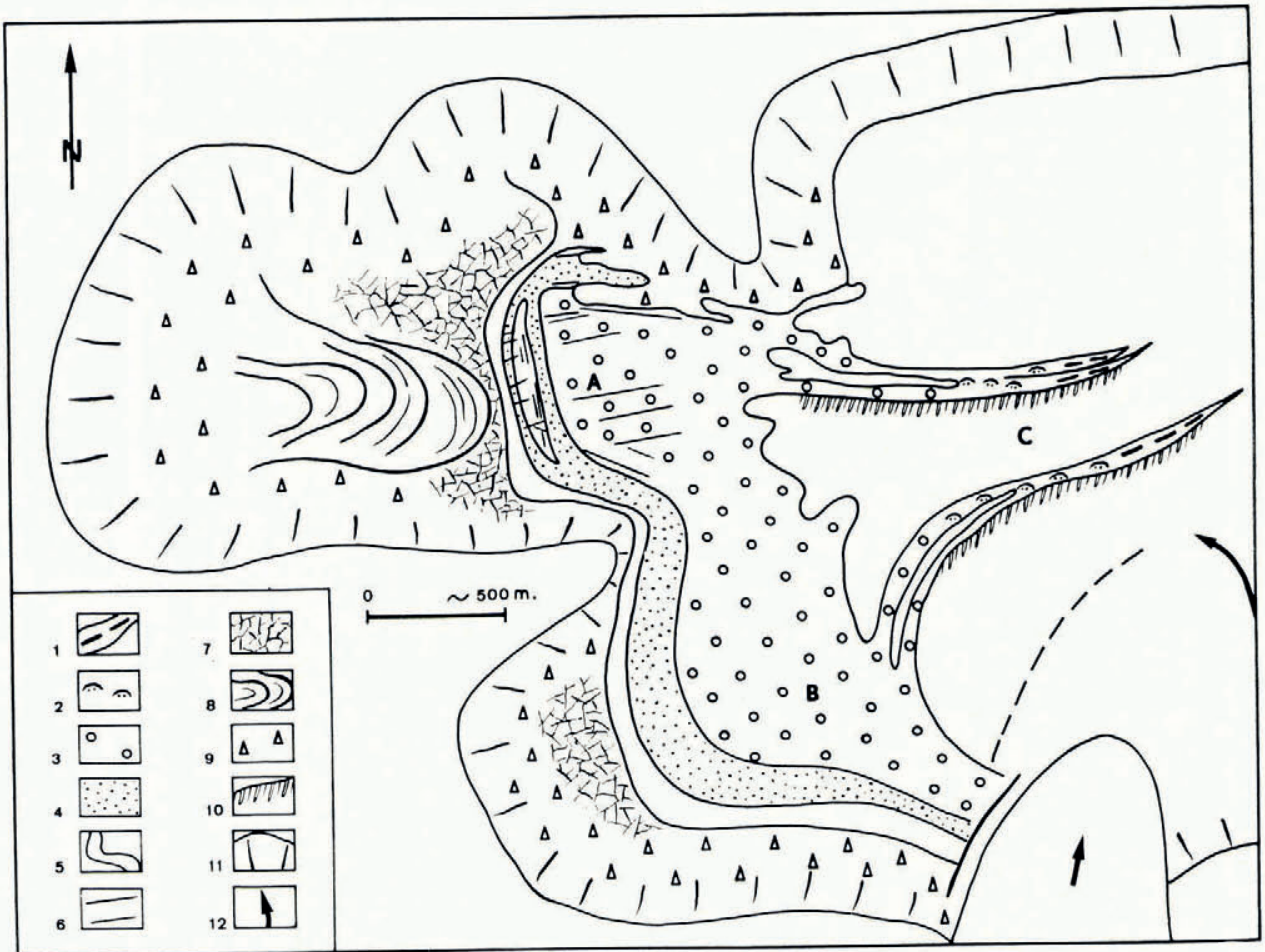

Fig. 2. The morainic field south-west of Altar Mountain

I. Slabs and blocks aligned in the shear zone. 2. Small hills of debris on glacier ice. 3. Zone of ice pyramids and ponds. Zone of continuous veneer of debris. 5. Marginal channel filled with regelation ice. 6. Localized shear planes filled with debris. 7. Polygonal pattern on ablation moraine. 8. Recessional cirque moraines. 9. Slope deposits. 10. Wind-blown snow accumulations near boulders. II. Mountain walls. I2. Ice-movement direction

(e) A zone of well-orientated morainic ridges. At least two orientations can be distinguished. This zone is also characterized by small frozen ponds in ablation hollows and by ice pyramids covered only by a thin veneer of debris.

In contrast, the great ridges of region C (Fig. 2) do not show such a zonation. If we except their inner flanks where the alignment of drift-snow accumulations behind boulders mask the debris and give rise to a curious pattern on the windward side, the differences from one place to another are more in relation to their distance from the margin of the ridge. Near the margin, aligned upstanding blocks and slabs appear at the ice surface; then, in a second zone, small mounds (less than I m. high) of finer particles cover glacier ice and are surrounded by blocks and slabs generally in a horizontal position; finally, there is a third zone with hummocks and small ponds, which is transitional to the inner part of the central body of the morainic field. After this general description let us consider the information given by the debris layers of zone c (Fig. 3).

\section{Formation of the Morainic Deposit}

It is possible to observe the appearance of different debris layers on the convex border of the glacier, and pits show their continuity within the ice. 


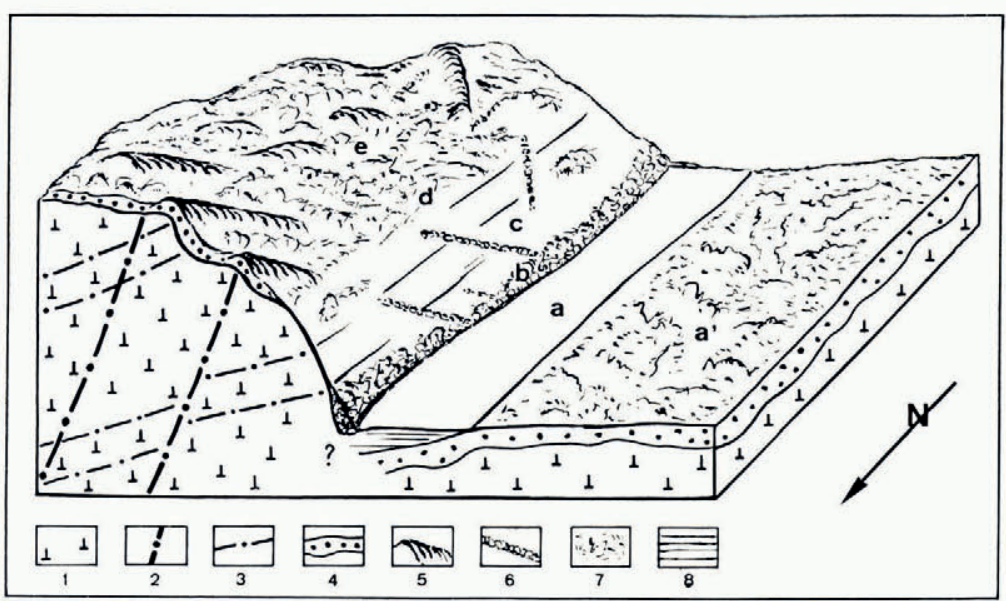

Fig. 3. The north-west margin of the morainic deposit

a. Marginal channel filled with regelation ice. $a^{\prime}$. Ablation moraine. b. Scree deposits. $c$. Glacier ice with shear planes filled with debris and debris layers of Weertman. $d$. Continuous veneer of moraines. $e$. Morainic hills and ridges.

1. Glacier ice. 2. Shear plane. 3. Weertman's debris layers. 4. Veneer of morainic deposit. 5. Morainic ridge. 6. Line of debris associated with a shear plane. 7. Morainic deposit at the surface. 8. Regelation ice in the marginal channel

The first type of debris layer consists of sub-horizontal planes filled with debris and separated from one another by pure glacier ice. The slight dip towards the interior of the glacier is due to the upwarping of flow lines at the margin.

Two distinct features characterize this type of debris layer:

(I) The debris is generally fine. Virtually all of the particles are less than $12 \mathrm{~mm}$. in diameter and the majority consist of coarse sand as shown by the grain-size distribution curves (group 2 of Figure 4).

(2) The ice contains regular trains of fine bubbles and tubular cavities aligned in the flow direction.

These two facts seem to indicate that the formation of the debris layers within the glacier is probably the result of a freezing-in process at the glacier bed and of the upwarping of the flow lines at the margin of the glacier. Weertman's (r96r) theory seems to be adequate to explain this type of debris layer.

It should also be noted that, in view of the fact that the glacier bed consists of rock fragments of different sizes, ranging from slabs and blocks to silt, a grain-size selective process is necessary to explain why only the fine fraction (less than $12 \mathrm{~mm}$. in diameter) is represented in the debris layers. This fact can be conveniently explained if it is assumed that a regelation layer is formed during the freezing-in process. The formation of this regelation ice can be accompanied by incorporation of the small particles while blocks and slabs remain in an unchanged position. Then the appearance of the debris layers at the glacier surface could be the result of upwarping of the flow lines. But all of the debris layers cannot be placed in the same category.

A second type can indeed be distinguished. As shown in Figure 3, fault planes cut the first type of debris layer, interrupting their continuity. Their age is therefore more recent than the sandy and silty bands, and their dip is steep. These shear planes are oblique to the margin of the glacier. It is possible to follow them as far as zone e (Fig. 3) of the central body of the morainic field where they form rectilinear morainic ridges. Indeed, slabs and gravel appear at 
the surface after having been scraped from the glacier bed, carried into the ice and ultimately transported along these planes. The grain-size distribution of these debris layers is in striking contrast to that of the first type, since they lack substantially in fine particles which cannot be easily carried into the ice by the shearing process.

Two directions of such faults can be observed. They correspond roughly to the orientations of fissures in the glacier ice in the central part of region C (Fig. 2). Thermal contraction of the ice at night, when the sky is clear and radiation from the Earth is very great, is responsible for the appearance of these fissures. Everyone who has camped on blue ice-fields has heard the cracking accompanying this process. In my opinion, these thermal-contraction fissures are further transformed into faults and localized shear planes at the margin of the glacier.

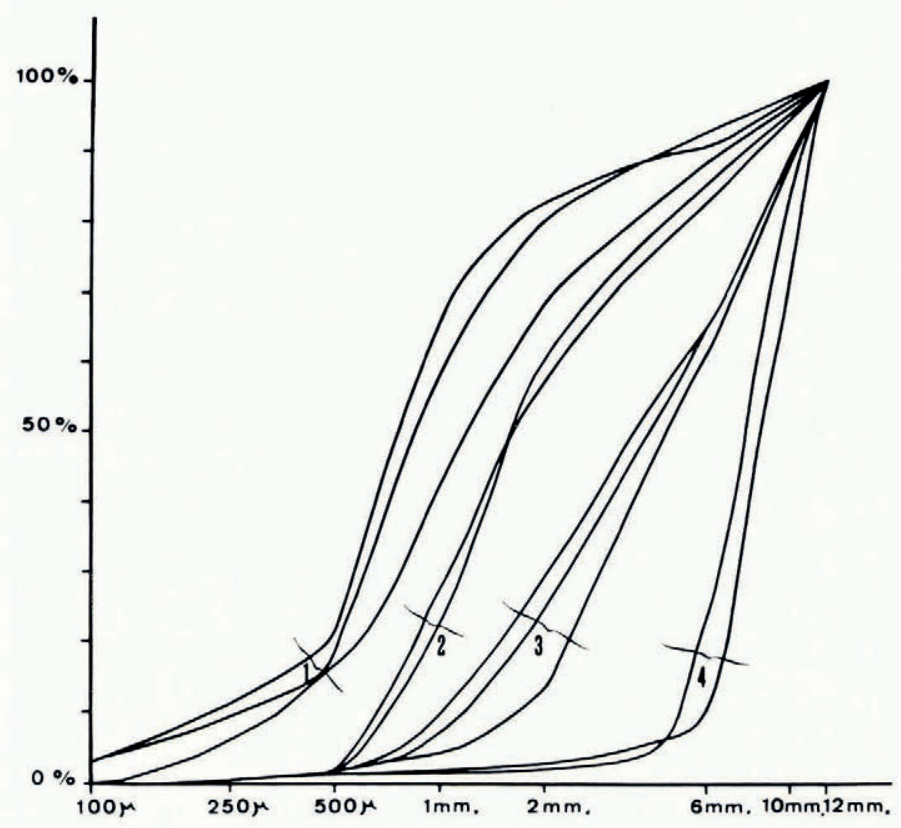

Fig. 4. Grain-size distribution curves of the fine fraction

Group 1. Cirque morainic deposits containing ground moraine. Group 2. Weertman's debris layers. Group 3. Fines in the morainic ridges. Group 4. Fines in the shear planes

A third type of debris layer is associated with major shear zones in the glacier at the boundary between stagnant and active ice. The grain-size distribution of the debris is similar to that of the previous case, except that blocks are more frequent.

The general pattern of this morainic deposit with its great ridges in the east (region $\mathrm{C}$; Fig. 2) has resulted from the appearance at the surface of these major shear zones, which exhibit a general convexity towards the cirque. At the margins of the ridges one can see a marked orientation of blocks and slabs with their long axes either parallel to or perpendicular to the ridge, and with a dip of about $20^{\circ}$ to the south.

These major shear zones have different ages; a new one is at present being formed, and it is represented in Figure 2 by a broken line. The appearance of aligned slabs at the surface reveals the shear zone in this stage.

Therefore, it is concluded that the morainic field examined here is the result of three different processes: 
(I) The upwarping of the ice, thereby including debris layers incorporated by a freezing-in process.

(2) The role of localized faults within the ice, thus permitting the debris to arrive at the surface after having been scraped from the glacier bed.

(3) The development of a shear zone between stagnant and active ice.

To these elements should be added supraglacial morainic boulders resting either directly on ice or on debris derived from the glacier bed. A good example is the occurrence in the deposit of carbonaceous siltstone boulders derived from Mount Feather. Large boulders of dolerite and Beacon Sandstone are also present. If these boulders are excluded, a petrographical study of the morainic deposit shows there is a general inversion in the debris in the different planes: dolerite fragments are abundant in the coarse fraction and quartz grains in the fine. A normal distribution is for example go per cent dolerite for the particles between 6 and $12 \mathrm{~mm}$., $5^{\circ}$ per cent between 500 microns and $\mathrm{I} \mathrm{mm}$., and 90 per cent of quartz grains between 100 and 250 microns. In a paper concerning glacial erosion in this area, it will be shown that the greater percentage of quartz grains in the fine fraction is the result of glacial abrasion of Beacon rocks, while dolerite, which is less sensitive to this process, is frostshattered and constitutes the majority of the fragments in the coarse fraction.

But granular disintegration of the Beacon Sandstone by frost action should not be forgotten. An ice hillock, entirely covered by Beacon Sandstone fragments and white derived sand, has been observed in the central part of the morainic deposit. This is supposed to have been an ancient boulder which protected the ice from ablation and has been completely disintegrated by frost action in the pores of the rock.

This ice pyramid is not the only sign of differential ablation; hollows occupied by frozen ponds are widespread on the morainic field and their size becomes larger with age. The absorption of solar radiation by the rock is the principal factor that allows such an evolutionary trend in this area, where the air temperature is constantly below freezing point.

\section{Conclusion}

The morainic deposit of upper Ferrar Glacier, near its boundary with the ice sheet in south Victoria Land, shows that both the shear hypothesis and Weertman's views are applicable; the debris can be either scraped from the glacier bed if it is coarse or be frozen in if it is sufficiently fine at the base of the ice sheet, and both shearing and upwarping occur at the glacier margin. Because of favourable circumstances, the debris layers of Weertman have been observed to be faulted by shear planes filled with coarse deposits.

MS. received ${ }_{4} 4$ March 1967

\section{REFERENCES}

Bishop, B.C. 1957. Shear moraines in the Thule area, northwest Greenland. U.S. Snow, Ice and Permafrost Research Establishment. Research Report i 7.

Schytt, V. I96r. Glaciology. II. Blue ice-fields, moraine features and glacier fluctuations. Norwegian-BritishSwedish Antarctic Expedition, 1949-52. Scientific Results, Vol. 4, E, p. 181-204.

Swinzow, G. K. 1962. Investigation of shear zones in the ice sheet margin. Thule area, Greenland. Fournal of Glaciology, Vol. 4, No. 32, p. 21 $5^{-29}$.

Weertman, J. 1961. Mechanism for the formation of inner moraines found near the edge of cold ice caps and ice sheets. Fournal of Glaciology, Vol. 3, No. 30, p. 965-78. 